\title{
НОРМАТИВНА СТРУКТУРА НАУКЕ ${ }^{1}$
}

Сажетак: У овом раду Роберт Мертон разматра четири опште норме научног етоса: универзализам, „комунизам“, безинтересност и организовани скептицизам. Он верује да ове норме, иако нигде нису кодификоване, представљају опште вредности међу научницима. Мертон одређује и истражује сваку од ових норми.

Кључне речи: наука, научни етос, универзализам, „комунизам“, безинтересност, организовани скептицизам

Наука, као и свака друга активност која укључује друштвену сарадњу, подлеже променљивој судбини. Онима који су одгајани у култури која науци даје истакнуто, ако не и владајуће место у поретку ствари, може да се учини тешко прихватљивим да наука није имуна на нападе, ограничења и сузбијања. Пишући у скорије време Веблен (Veblen) је могао да примети да је вера у науку западне културе била неограничена, неоспорна и без премца. Побуна унутар науке чинила се тако мало вероватном, да је могла да забрине само бојажљиви академски ум који размишља о свим, па и слабо извесним могућностима, док се сада намеће пажњи како научника, тако и лаика. Локалне заразе анти-интелектуализма прете да поприме размере епидемије.

\section{Наука и друштво}

Почетни или актуални напади на интегритет науке довели су научнике до тога да освесте сопствену зависну позицију у односу на одређене типове друштвених структура. Постоје манифести и обзнане научних удружења посвећени односима науке и друштва. Нападнута институција у обавези је да изнова испита своје темеље, изнова постави своје циљеве и изнова потражи резоне којима се управља. Криза захтева самопроцену. Суочени са изазовима упућеним њиховом начину живота, научници су грубо гурнути у стање акутне самосвести: свести о себи као интегралном елементу друштва, са одговарајућим обавезама и интересима. ${ }^{2}$ Кула од слоноваче уздрмана је сталним нападима.

\footnotetext{
${ }^{1}$ Оригинално објављено као “Science and Technology in a Democratic Order", Journal of Legal and Political Sociology 1 (1942): 115-26; касније (1949) објављено као "Science and Democratic Social Structure" y: Robert K. Merton, Social Theory and Social Structure. (Рад је уз мање измене поново објављен 1973. године као: “The Normative Structure of Science”, у књизи: Robert K. Merton, The Sociology of Science: Theoretical and Empirical Investigations, The University of Chicago Press, pp. 267278, што је изворник овог превода - прим. ред.)

${ }^{2}$ Откако је 1942. године овај рад написан, постало је јасно да је бомбардовање Хирошиме
} 
Након дужег периода релативне сигурности, током којег се стицање и ширење знања винуло на водеће, ако не и прво место међу културним вредностима, научници су сада приморани да оправдавају токове науке човечанству. На овај начин они су обишли пун круг, све до тачке поновног рађања науке у модерном свету. Пре три века, када је институција науке патила од оскудице независних јемаца локалне подршке, филозофи природе су на сличан начин били приморани да оправдавају науку као средство за постизање културолошки установљених циљева економске употребљивости и величања Бога. Бављење научним радом у она времена није било препознато као вредност само по себи. Но, путем неисцрпног низа достигнућа, потчињено је постало главно, а средство - циљ. Утврђен на овај начин, научник је дошао у позицију да себе сматра независним од друштва и да науку третира као подузеће коме не треба додатно оправдање, које обитава у друштву али није у његовој надлежности. Био је потребан чеони напад на аутономију науке да се овај самоуверени изолационизам претвори у реалистичније учешће у револуционарном сукобу култура. Придруженост проблема довела је до појашњења и реафирмације етоса модерне науке.

Наука је варљиво инклузиван појам који се односи на перјаницу јасно разграничених али међусобно повезаних јединица. Најчешће се користи за означавање (1) скупа карактеристичних метода којима се знање потврђује; (2) залихе акумилираног знања које се накупило употребом ових метода; (3) скупа културолошки условљених вредности и неписаних правила (mores) која регулишу активности које се могу назвати научним; или (4) све комбинације већ наведеног. Ми се овде прелиминарно бавимо културном структуром науке, што ће рећи - једним ограниченим аспектом науке као институције. Стога ћемо узети у разматрање, не научне методе, већ неписана друштвена правила која их ограђују. Неоспорно, методолошки канони су често истовремено и техничке нужности и моралне принуде, али ћемо се овде бавити само потоњим. Ово је оглед из домена социологије науке, а не методолошко истраживање. Такође, нећемо се овде бавити стварним резултатима научног рада (хипотезе, правилности, законитости), осим ако се не односе на општеприхваћене друштвене ставове усмерене на науку. Ово није полиматска авантура.

\section{Етос науке}

Етосом науке се назива афективно (ин)тониран комплекс вредности

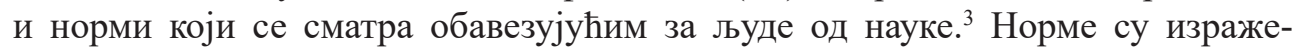
не у виду препорука, прописа, преференци и дозвола. Легитимност им дају

пробудило код већег броја научника свест о последицама њиховог рада по друштво.

${ }^{3}$ О концепту етоса видети: William Graham Sumner, Folkways (Boston: Ginn, 1906), pp. 36 и даље; Hans Speier, “The Social Determination of Ideas," Social Research 5 (1938): 196 и даље; Max Scheler, Schriften aus dem Nachlass (Berlin, 1933), 1: 225-62. Албер Баје (Bayet), у књизи која се бави овом темом, опис и анализу убрзо замењује проповедањем; видети његов La morale de la science (Paris, 1931). 
институционал(изова)не вредности. Ове императиве, који се преносе путем правила и примера, са апаратом принуде у казни, научник интернализује и тако обликује своју научну савест или, ако је неком милије да се послужи изразом новијег датума, свој супер-его. Иако научни етос није кодификован, ${ }^{4}$ он може да се изведе из моралног консензуса научника, онако како је он нашао израз кроз употребу и обичаје, као и у безбројним списима на тему научног духа и моралној осуди усмереној ка прекршајима на пољу научне етике.

Испитивање етоса модерне науке је пуки, ограничени увод у шири проблем: компаративне студије институционалне структуре науке. Иако су детаљније монографије које окупљају материју потребну за компаративни приступ малобројне и раштркане, оне пружају извесни основ за провизорну претпоставку да је „науци у демократском поретку, чији је научни етос интегрални део, дата могућност развоја“. Ово не значи да је бављење науком строго ограничено на демократска друштва. ${ }^{5}$ Најразличитији видови друштвених структура дају подршку науци у извесној мери. Потребно је само сетити се да су двојица Медичијевих спонзорисала Академију експеримента (Accademia del Cimento); да је Чарлс II доспео у историју својом повељом лондонском Краљевском друштву и меценством опсерваторије у Гриничу; да је француска Академија наука основана под покровитељством Луја XIV, а по Колберовом (Colbert) савету; да је, пошто га је Лајбниц (Leibniz) сатерао уз зид, Фридрих I финансирао Академију у Берлину, те да је Петар Велики установио петроградску Академију наука (како би побио тврдње да су Руси варвари). Али, ове и сличне историјске чињенице не доказују неко произвољно удруживање науке и друштвених структура. Постоји дубље питање односа научних достигнућа и научних потенцијала. Наука се развија у различитим друштвеним структурама, то је ван сваке сумње - али које од њих су кадре да обезбеде институционални контекст за најпотпунији развој?

Институционални циљ науке је проширење научно потврђеног знања. Технички методи који се у ту сврху користе пружају нам релевантну дефиницију знања: то су емпиријски потврђени и логички целовити искази правилности (који су, у својим последицама, предвиђања). Институционални императиви (mores) изведени су из циља и метода. Читава структура техничких и моралних норми испуњава крајњи циљ. Техничка норма емпиријског доказа, адекватног

\footnotetext{
${ }^{4}$ Како Баје (Bayet) примећује: „Тај морал (науке) није имао своје теоретичаре, али је имао своје мајсторе. Није изразио њен идеал, већ му је служио: он је уткан у само постојање науке“ ( $\mathrm{La}$ morale de la science, p. 43)

${ }^{5}$ Токвил (Tocqueville) је отишао даље: „Будућност ће показати да ли се такве страсти, тако ретке и тако плодотворне, исто тако лако рађају и развијају и у демократским друштвима као у аристократским. Ја то тешко могу веровати.“ (Алексис де Токвил, О демократији у Америци; превео с француског Живојин Живојиновић, Сремски Карловци: Издавачка књижарница Зорана Стојановића; Титоград: ЦИД, 1990, стр. 410). Видети једно другачије тумачење историјске евиденције: „Немогуће је успоставити једноставну узрочну везу између демократије и науке, и тврдити да демократско друштво са̂мо може да обезбеди плодно тло за развој науке. Ипак, не може бити пука случајност да је наука заиста цветала у демократским периодима“ (Henry Е. Sigerist, "Science and Democracy," Science and Society 2 [1938]: 291)
} 
и поузданог, предуслов је трајне истинитости предвиђања; техничка норма логичке доследности - предуслов систематичног и валидног предвиђања. Правила научне делатности су методолошки утемељена, али разлог што се узимају за обавезна не треба тражити у томе што су процедурално ефикасна - већ у томе што се верује да су исправна и ваљана. Она су у једнакој мери морални и технички прописи.

Сматра се да четири врсте институционалних императива - универзализам, комунизам, безинтересност, организовани скептицизам - чине етос модерне науке.

\section{Универзализам}

Универзализам $^{6}$ налази непосредни израз у канонском правилу да тврдње чију истинитост треба доказати, који год да је њихов извор, подлежу унапред установљеним објективним критеријумима: у складу са посматрањем и већ потврђеним знањем. Прихватање или одбацивање тврдњи које траже своје место на научним листама не сме да зависи од личних или друштвених одлика аутора; његова раса, националност, религија, класа и лични квалитети су као такви ирелевантни. Објективност спречава партикуларизам (подвајање). Чињеница да се научно потврђене формулације односе у том специфичном смислу на објективне секвенце и узајамне односе противи се сваком покушају успостављања повлађивачких критеријума валидности. Нирмбершки декрет не може да поништи Хабер(-Бошов) поступак као што ни англофоб не може да побије закон гравитације. Шовиниста може да избрише имена туђинских научника из историјских књига, али њихове формуле остају незаменљиве науци и технологији. Колико год да је финални корак напред echt-deutsch (истински немачки) или стопостотно амерички, извесно туђинско присуство је закулисни чинилац у сваком научном напретку. Императив универзализма дубоко је укорењен у над-личном карактеру науке.

Међутим, институција науке је део шире друштвене структуре у коју није увек сасвим интегрисана. Када се култура успротиви универзализму, научни етос се нађе под озбиљним оптерећењем. Етнички центризам није компатибилан са универзализмом. Нарочито у времена међународних сукоба, када је доминантна дефиниција ситуације таква да ставља акценат на лојалност нацији, човек од науке се нађе на удару конфликта императива: научног универзализма и етноцентричног партикуларизма. ${ }^{7}$ Структура ситуације у којој се

\footnotetext{
${ }^{6}$ За основну анализу универзализма у друштвеним односима видети: Talcott Parsons, The Social System (New York: Free Press, 1951). За изношење уверења да је „наука потпуно независна од државних граница, раса и вероисповести“, видети резолуцију коју је донело The Council of the American Association for the Advancement of Science, Science 87 (1938): 10; такође, "The Advancement of Science and Society: Proposed World Association," Nature 141 (1938): 169.

${ }^{7}$ Ово остаје како је написано 1942. До 1948. године, политичке вође Совјетске Русије су појачале свој нагласак на руском национализму и почеле да инсистирају на „националном“ карактеру
} 
он онда нађе одређује врсту улоге која се позива у игру. Човек од науке може да се преметне у човека рата - и да се понаша одговарајуће тој улози. Тако je 1914. године манифест деведесеттројице немачких научника и учењака међу којима су били Бајер (Baeyer), Брентано (Brentano), Ерлих (Ehrlich), Хабер (Haber), Едвард Mejep (Meyer), Оствалд (Ostwald), Планк (Planck), Шмолер (Schmoller) и Васерман (Wasserman) - отворио полемику у којој су Немци, Французи и Енглези устројили своје политичке личности под кринком науке. Трезвени научници су доводили у сумњу „непријатељске“ доприносе - оптужбама за националистичку пристрасност, букачење, интелектуално непоштење, некомпетентност и недостатак креативних капацитета. ${ }^{8}$ Но, ово одступање од универзализма као норме у ствари је претпостављало важење саме норме. Јер, националистичка предрасуда је срамна само уколико се о њој суди према стандардима универзализма; унутар другачијег институционалног контекста, она бива редефинисана као врлина - патриотизам. На овај начин се, кроз процес осуде њиховог нарушавања, неписани закони науке изнова потврђују.

Чак и под притиском да чине супротно, научници свих националности држали су се универзалистичких стандарда у директним односима. Интернационални, над-лични и практично анонимни карактер науке је реафирмисан. ${ }^{9}$

науке. Тако, у уводном чланку, „Против буржоаске идеологије космполитизма“, Вопрось философии, № 2 (1948), како је преведено у: The Current Digest of the Soviet Press 1, no. 1 (1 February 1949), 9, стоји: „Само космополита без домовине, дубоко неосетљив на тренутни положај науке, може са презривим незнањем да пориче постојање шаренила националних форми у којима наука живи и развија се. На место стварне историје науке и конкретних путева њеног развоја, космополита поставља измишљене појмове наднационалне, бескласне науке, такорећи, лишене богатства националних боја, лишене живог сјаја и посебне одлике народног стваралачког рада и претворене у неку врсту бестелесног духа ... Марксизам-лењинизам разбија у комаде космополитске фикције о бескласној, не-националној, 'универзалној' науци и недвосмислено доказује да је наука, као и сва култура у модерном друштву, национална у свом облику и класна у садржају“. Овај начин гледања не прави разлику између два одвојена питања: прво, културни контекст у било којој држави или друштву може да усмери научнике да се усредсреде на одређене проблеме, да буду осетљиви на једне, а не на друге проблеме на научним границама. Ово је још одавно уочено. Али то се у основи разликује од другог питања: критеријуми на основу којих одређене тврдње могу да се сматрају научним нису ствар државног/националног укуса или културе. Пре или касније, сукоби око супротстављених тврдњи о научној валидности се разрешавају уз помоћ универзалистичких критеријума.

${ }^{8}$ За информативну збирку таквих докумената видети: Gabriel Pettit \& Maurice Leudet, Les allemands et la science (Paris, 1916). Феликс де Дантек (Félix de Dantec), на пример, открива да су и Ерлих и Bajсман (Weismann) извршили типично немачку превару у свету науке. („Блеф немачке науке“ ["Le bluff de la science allemande”]). Пјер Дијем (Pierre Duhem) закључује да је „геометријски дух“ немачке науке угушио „дух префињености“, La science allemande (Paris 1915). Херман Колерман (Hermann Kellermann), Der Krieg der Geister (Weimar, 1915) негује исти дух на супротној страни. Сукоб се наставио и у послератном периоду; видети: Karl Kherkhof, Der Krieg gegen die Deutsche Wissenschaft (Halle, 1933)

${ }^{9}$ Видети исповедање вере професора Е. Глеја (Gley) (y: Petit \& Leudet, Les allemands et la science, p. 181): „Не може да постоји немачка, енглеска, италијанска или јапанска истина више него француска. Говорити о немачкој, енглеској или француској науци је тврдња која противречи самој идеји науке“. Видети такође потврде Грасеа (Grasset) и Ришеа (Richet), ibid 
(Пастерово [Pasteur] „Научник има домовину, наука не“ - Le savant a une patrie, la science n'en a pas.) Порицање норме се схватало као вероломство.

Универзализам даље налази израза у захтеву да се талентованима омогући каријера. Оправдање је обезбеђено институционалним циљевима. Ограничити научну каријеру на основима другачијим од недостатка компетенције значи утицати на напредовање сазнања. Пробитачност и морал се слажу. Отуд аномалија да Чарлс II зазива неписане законе науке како би укинуо одлуку Краљевског друштва о намераваном искључењу Џона Гронта (Graunt), политичког аритметичара, те и његових (краљевих) упута да „ако нађу још таквих мајстора, треба да се постарају да их без одлагања приме у своје редове“.

Овде опет етос науке може да одступи од оног који је на снази у ширим друштвеним оквирима. Може да се догоди да научници усвоје стандарде касте и да своје редове затворе за оне нижег статуса, без обзира на капацитете и достигнућа. Веома префињене идеологије су уведене да се прикрије некомпатибилност неписаних правила касте и институционалних циљева науке. Припадници нижих касти морају бити приказани као инхерентно неспособни за научни рад или се, у најмању руку, вредност њихових доприноса мора систематски срозавати. „Из историје науке се може извести закључак да су оснивачи истаживања у физици, као и велики проналазачи од Галилеја и Њутна до пионира физике нашега доба, готово искључиво Аријевци, претежно нордијске расе“. Преиначујућа фраза „готово искључиво“ препозната је као недовољан основ да се неприпадајућима порекне свака заслуга за научно достигнуће. Идеологија је стога надувена увођењем концепта „добре“ и „лоше“ науке; реалистична, прагматична наука Аријеваца супротставља се догматској, формалистичкој науци не-Аријеваца. ${ }^{10}$ Или су основи за искључење тражени у ван-научним капацитетима људи од науке као непријатеља државе или цркве. ${ }^{11}$ Отуд се и представници културе која се одриче универзалистичких стандарда уопштено осећају спутаним да макар на речима подрже овај принцип у научним круговима. Универзализам је лукаво потврђиван у теорији и сузбијан у пракси.

Колико год да је неадекватно стављен у праксу, етос демократије укључује универзализам као владајући водећи принцип. Демократизација је једнака прогресивној елиминацији стега око употребе и развоја друштвено вредних капацитета. Објективни критеријуми остварености, а не статусне фиксације, одликују отворено, демократско друштво. У оној мери у којој стеге и даље постоје, оне се доживљавају као препреке на путу до пуне демократизације.

10 Johannes Stark, Nature 141 (1938): 772; “Philipp Lenard als deutscher Naturforscher," Nationalsozialistische Monatshefte 7 (1936): 106-12. Ово може да се упореди са Дијемовим (Duhem) разликовањем „немачке“ и „француске“ науке.

${ }^{11}$ „Нисмо их уклонили ['марксистичке оспораваоце'] као представнике науке, већ као поборнике политичке доктрине која заговара свргавање свих поредака. И ми смо морали бити још одлучнији у томе, јер им је изгледало да владајућа идеологија вредносно-неутралне и непринципијелне науке свесрдно омогућава да наставе са својим плановима. Нисмо ми ти који су се огрешили о достојанство слободне науке..." Bernhard Rust, Das nationalsozialistische Deutschland und die Wissenschaft (Hamburg: Hanseatische Verlagsanstalt, 1936), p. 13 
Стога, у оној мери у којој либерално (laissez-faire) демократски модел дозвољава акумулацију компаративих предности за одређене сегменте популације - разлика који нису везане за показане разлике у капацитетима, утолико демократски процес води ка појачавању регулације коју спроводе политички ауторитети. Под околностима које се мењају, морају се увести нове техничке форме организације да се очува и прошири једнакост могућности. Може се указати потреба да политички апарат стави демократске вредности у праксу и одржи универзалистичке стандарде.

\section{„Комунизам“}

„Комунизам“ у не-техничком и пренесеном смислу заједничког власништва над добрима, је други по реду интегрални елемент научног етоса. Битни налази науке производ су друштвене сарадње и припадају заједници. Они чине заједничко наслеђе у коме је удео појединца јако ограничен. Закон или теорија који носе нечије име не улазе у искључиво власништво свог проналазача и његових наследника, нити им неписани закони дају посебна права употребе и преноса. Имовинска права у науци скресана су на голи минимум начелима научне етике. Научниково право на „његову“ интелектуалну „својину“ ограничено је на признање и углед који су, ако институција функционише са имало ефикасности, отприлике у пропорционалном односу са значајем његових доприноса напретку заједничког фонда знања. Епонимија је тако - као у примерима коперникански систем, Бојлов закон - истовремено механизам и памћења и сећања.

Будући да је такав институционални нагласак на признању и угледу као једином имовинском праву научника кад су његова открића у питању, интересовање за приоритет у науци постаје „нормална“ реакција. Контроверзе око приоритета којима је испресецана историја модерне науке последица су институционалног нагласка на оригиналности. ${ }^{12}$ Тако се јавља компетитивна сарадња. Резултати ривалства постају заједничка својина, ${ }^{13}$ а углед иде ономе ко их је постигао. Нације полажу права на предност и нови прилози научном комонвелту (заједници народа) обележени су именима припадника нација: ос-

\footnotetext{
${ }^{12}$ Њутн (Newton) је писао на основу мукотрпно стеченог искуства када је запазио да је „(природна) филозофија таква дрска и свадљива дама да је потребно искуство судских парничења да би човек могао са њом да изађе на крај“. Роберт Хук (Hooke), социјално покретљив појединац, чији је успон на друштвеној лествици био заснован искључиво на његовим научним достигнућима, био је познати „парничар“.

${ }^{13}$ Иако је могуће да је у некој мери одређена тржишном логиком ширег друштва, професија попут медицинске прихвата научно знање као заједничко власништво. Видети: R. H. Shryock, "Freedom and Interference in Medicine,” The Annals 200 (1938): 45. „Медицинска професија ... се обично мрштила на патенте које су регистровали медицинари .... Уобичајена професија ... је заступала овако становиште против приватних монопола још од настанка ауторских права у седамнаестом столећу“. Настаје двосмислена ситуација у којој се одбацује подруштвљавање медицинске праксе у круговима где се не доводи у питање подруштвљавање знања.
} 
ведочимо само контроверзу која бесни око ривалских полагања права Њутна и Лајбница на диференцијални рачун. Али, све ово не доводи у питање статус научног сазнања као заједничке имовине.

Институционална концепција науке као дела јавног домена повезана је са императивом дељења сазнања. Тајност је антитеза ове норме; потпуна и отворена комуникација њена примена. ${ }^{14}$ Притисак на ширење резултата је стимулисан институционалним циљем померања граница сазнања, као и подстицајем добијања признања које је, разуме се, условљено објављивањем. Научник који не пренесе своја важна открића научном братству - дакле, један Хенри Кевендиш (Cavendish) - постаје мета амбивалентних реакција. Цењен је због свог талента, и може бити и због своје скромности. Али, са становишта институције, његова је скромност озбиљно погрешно усмерена у погледу моралне принуде на дељење научног богатства. Иако лаички, коментар Олдоса Хакслија (Huxley) о Кевендишу (Cavendish), у вези са овим, је просветљујућ: „Наше уважавање његовог генија разводњено је извесним неодобравањем; осећамо да је такав човек себичан и штетан по друштво“. Епитети овде имају нарочит карактер инструкција, јер имплицирају прекршај недвосмисленог институционалног императива. Без обзира што није учињено из задњих намера, прикривање научног открића бива осуђено.

Заједнички карактер науке даље се огледа у чињеници да научници препознају сопствену зависност од културног наслеђа на које не полажу икаква посебна права. Њутнова изрека - „Ако сам и видео даље, то је зато што сам стајао на раменима дивова“ - израз је истовремено осећаја дуга према заједничком наслеђу и свести о суштински кооперативној и селективно кумулативној природи научног достигнућа. ${ }^{15}$ Понизност научног генија није само културолошки подесна, већ проистиче из свести да научни напредак укључује и допринос прошлих и будућих нараштаја. Није се Максвел (Maxwell) препуштао митопоетичкој концепцији историје - био је то Карлајл (Carlyle).

Комунизам научног етоса некомпатибилан је са дефиницијом технологије као „приватног власништва“ у капиталистичкој економији. Савремени

\footnotetext{
14 Упореди са Берналом, који примећује: „Раст модерне науке подударио се са коначним одбацивањем идеала тајности“. Бернал наводи изванредан пасус из Реамира (Réaumur, L'Art de convertir le forgé en acier) у коме се морална принуда на објављивање налаза нечијег истраживања изричито повезује са другим елементима етоса науке. На пример: „било је људи који су сматрали да је чудно што сам објавио тајне које није требало да буду откривене ... Да ли је заиста сигурно да су наша открића толико наша да јавност нема право на њих, да јој она, на неки начин, не припадају? ... да ли преовладавају случајеви у којима можемо да кажемо да смо апсолутни власници наших открића? ... Наша прва обавеза је према нашој земљи, али ми такође имамо обавезу према остатку света и они који раде на усавршавању наука и уметности морају да се сматрају грађанима целог света“ (J. D. Bernal, The Social Function of Science [New York: Macmillan, 1939] pp. 150-51)

${ }^{15}$ Од извсног је значаја то да је Њутнов афоризам стандардизована фраза која изнова налази примену барем од дванаестог века. Чини се да је зависност открића и изума од постојеће културне основе била уочена неко време пре него што су је формулисали модерни социолози. Видети: Isis 24 ( 1935): 107-9; 25 (1936): 451-52
} 
списи о „фрустрацији науке“ одраз су овог конфликта. Патенти прокламују ексклузивна права употребе и, често, неупотребе. Задржавање проналазака побија начела научне производње и дељења, као што се може видети на примеру судске одлуке у случају Сједињених Држава против American Bell Telephone Со.: “Проналазач је онај ко је изумео нешто вредно. То је његово апсолутно власништво. Он је у могућности да сачува знање о томе од јавности.“16 Реакције на ову конфликтну ситуацију биле су разнолике. Као одбрамбену меру, неки су научници одабрали да патентирају своје дело како би осигурали своје право да га учине доступним за јавну употребу. Ајнштајн (Einstein), Миликен (Millikan), Комптон (Compton), и Ленгмир (Langmuir) су регистровали патенте. ${ }^{17}$ Научници су под притиском да постану промотери нових економских предузећа. ${ }^{18}$ Други су решење потражили у заговарању социјализма. ${ }^{19}$ Обе ове позиције - она која захтева економску зараду од научних достигнућа и она где је централан захтев да се друштвени систем мења како би науци било омогућено да настави са својим задатком - одраз су мимохода унутар концепције интелектуалне својине.

\section{Безинтересност ${ }^{20^{*}}$}

Наука, као што је уопштено случај са професијама, подразумева безинтересност као основни институционални чинилац. Безинтересност не треба поистовећивати са алтруизмом - нити интересна делања са егоизмом. Повлачења таквих једнакости настају из забуне око институционалних и мотивацијских нивоа анализе. ${ }^{21}$ Страст за сазнањем, докона радозналост, човекољубље и мноштво других посебних мотива приписују се научницима. Потрага за препознатљивим мотивима делује као странпутица. Рекло би се пре да је препознатљив образац институционалне контроле оно што карактерише понашање научника. Jep, када институција пропише безинтересност, почиње да бива у интересу на-

\footnotetext{
${ }^{16} 167$ U. S. 224 (1897), цитирано према: B. J. Stern, "Restraints upon the Utilization of Inventions," The Annals 200 (1938): 21. За даљу расправу, видети Стернове радове који су тамо цитирани, такође: Walton Hamilton, Patents and Free Enterprise, Temporary National Economic Committee Monograph no. 31 (1941)

${ }^{17}$ Hamilton, Patents and Free Enterprise, p. 154; J. Robin, L'oeuvre scientifique: sa protection-juridique (Paris, 1928)

${ }^{18}$ Vannevar Bush, “Trends in Engineering Research,” Sigma Xi Quarterly 22 (1934): 49

${ }^{19}$ Bernal, The Social Function of Science, pp. 155 и даље

${ }^{20}$ Мертонов оригинални термин “Disinterestedness” је био превођен и као „незаинтересованост“ (видети: Марко Шкорић, Социологија науке: мертоновски и конструктивистички програми, Нови Сад; Сремски Карловци: Издавачка књижарница Зорана Стојановића, 2010). (nрuм. ред.)

${ }^{21}$ Talcott Parsons, “The Professions and Social Structure," Social Forces 17 (1939): 458-59; упореди: George Sarton, The History of Science and the New Humanism (New York, 1931), p. 130 и даље. Разликовање институционалних принуда и личних мотива је кључна, иако у многоме, имплицитна замисао марксистичке социологије.
} 
учника да се прилагоде болним санкцијама, те - у зависности од тога у којој је мери норма интернализована - мукама психолошког конфликта.

Практично одсуство преваре у аналима науке, које делује изузетно када се упореди са оним што знамо о другим сферама људске делатности, повремено се приписује личним квалитетима научника. Тиме се имплицира да се научници регрутују из редова оних који показују изванредан степен моралног интегритета. Нема, међутим, задовољавајућег доказа да је то тако; пуно прихватљивије објашњење може да се пронађе у препознатљивим карактеристикама науке као такве. Будући да подразумева проверљивост резултата, научно истраживање је подложно детаљном испитивању од стране колега-стручњака. Другим речима - а ван сваке сумње је да посматрање може бити схваћено као велеиздаја (lese majesty енг. / lèse-majesté фр.) - научне активности подлежу ригорозним политикама, до ступња који можда нема премца у било ком другом пољу људског деловања. Потреба за безинтересносношћу има чврсту основу у јавном и проверљивом карактеру науке, и ова околност, може се претпоставити, допринела је интегритету људи од науке. Постоји ривалство на пољу науке, ривалство појачано приоритетом као критеријумом остварености, и у таквим условима може се веома лако јавити тежња да се баци сенка на ривале уз помоћ непримерених средстава. Али такви импулси не наилазе на плодно тло у пољу научног истраживања. Секташење, неформалне дружине, бројне, али тривијалне публикације - ове и друге технике могу се искористити за величање себе. ${ }^{22}$ Но, генерално спорне тврдње су, како изгледа, занемарљиве и без већег ефекта. Практична примена норматива безинтересности налази ефектну подршку у одговорности научника према колегама. Диктат друштвене одговорности и експедитивност су овде у великој мери у слози, што је ситуација која погодује институционалној стабилности.

С тим у вези, поље науке се унеколико разликује од осталих професија. Научник не стоји лицем у лице са лаичком клијентелом као што је то случај са лекаром или адвокатом, на пример. Тиме је и могућност искоришћавања поводљивости, незнања и зависног положаја лаика значајно смањена. Превара, блефирање и неодговорне тврдње (шарлатанство) су чак и мање заступљени него у „услужним“ делатностима. У оној мери у којој директна веза научника и лаика постаје главна ствар, развијају се и иницијативе да се заобиђу неписана правила науке. Злоупотреба стручног ауторитета и стварање псеудо-наука се уводе у игру када се контролна структура квалификованог колегијума онеспособи. ${ }^{23}$

Веома је вероватно да су репутација науке и њен узвишен статус у очима лаика великим делом последице технолошких достигнућа. ${ }^{24}$ Свака нова технологија сведо-

\footnotetext{
${ }^{22}$ Видети разматрање: Logan Wilson, The Academic Man (New York: Oxford University Press, 1941 ), р. 201 и даље.

${ }^{23}$ Упореди: R. A. Brady, The Spirit and Structure of German Fascism (New York: Viking, 1937), поглавље 2; Martin Gardner, In the Name of Science (New York: Putnam's, 1953)

${ }^{24}$ Френсис Бекон (Bacon) је изнео једну од раних и најјезгровитијих формулација овог популарног прагматичког начела: „Дакле, ова два начела, активно и посматрачко, представљају једну исту ствар, и оно што је код дејства најкорисније, код знања је најистинитије." (Френсис Бекон, Истинита упутства за тумачете природе - Нови органон \& Велика обнова; превео Милан
} 
чи о интегритету научника. Наука остварује своје тврдње. Међутим, њен ауторитет може бити - и јесте - присвојен за потребе разних интереса, баш зато што лаик није у позицији да разликује спорна полагања права на тај ауторитет од правих. Наводне научне тврдње тоталитаристичких портпарола о раси или економији или историји су за неупућене лаике на истој нози са извештајима у штампи о ширењу универзума или механици таласа. У оба случаја, могу се наћи у сукобу са здравим разумом. У најмању руку, митови ће деловати прихватљивије и свакако јасније јавном мнењу него ли акредитоване научне теорије, јер су ближе искуству здравог разума и културној пристрасности. Дакле, делом под утицајем научних достигнућа, шира популација постаје мање имуна на нове форме мистицизма преточене у наизглед научну терминологију. Позајмљени научни ауторитет доноси престиж не-научним доктринама.

\section{Организовани скептицизам}

Као што смо видели у претходном поглављу, организовани скептицизам је на различите начине узајамно повезан са другим елементима научног етоса. Ово се узима за мандаторно и са методолошког и са институционалног становишта. Привремена суспензија суда и непристрасно испитивање веровања у условима које диктирају емпиријски и логички критеријуми су, с времена на време, увлачили науку у сукобе са другим институцијама. Наука, која поставља питања чињеница, укључујући све могућности које се дотичу сваког аспекта природе и друштва, може доћи у конфликт са другачијим приступима тој истој материји, окорелим и често ритуализованим од стране других институција. Научни истраживач не поштује расцеп измећу светог и световног, између онога што захтева некритичко поштовање и онога што се да објективно анализирати.

Као што смо раније истакли, ово је наизглед извор револта против такозваног задирања науке у друге сфере. Такав је отпор код организоване религије данас мање значајан, када се упореди са оним код економских и политичких група. Опозиција се може наћи и подалеко од увођења специфичних научних открића која, како се чини, поништавају одређене догме цркве, економије или државе. Она је пре у дифузном, често и не баш одређеном, схватању да скептицизам представља претњу важећој расподели снага. Сукоб постаје наглашен кад год наука прошири своја истраживања на нова подручја, на којима већ постоје институционализовани ставови - и обратно, кад год друге институције прошире своју контролу на поље науке. У модерним тоталитарним друштвима, анти-рационализам и централизација институционалне контроле заједно служе да се ограниче видици предвиђени за научни рад.

са енглеског језика превели:

Марко Дабетић, Сандра Гавриловић, Татијана Марикановић,

Млађан Стевановић и Милош Јовановић стручна редакција: Милош Јовановић

Милетић, Београд: Службени гласник, 2009, стр. 123.) 


\section{Литература}

Bayet, A. (1931) La morale de la science. Paris: Les Presses Universitaires de France.

Bernal, J. D. (1939) The Social Function of Science. New York: Macmillan.

Brady, R. A. (1937) The Spirit and Structure of German Fascism. New York: Viking

Bush, V. (1934) “Trends in Engineering Research”. Sigma Xi Quarterly 22(2): 45-51.

Duhem, P. (1915). La Science Allemande. Paris: Hermann.

Gardner, M. (1953) In the Name of Science. New York: Putnam's.

Hamilton, W. (1941) "Patents and Free Enterprise". Temporary National Economic Committee Monograph 31.

Kellermann, H. (1915) Der Krieg der Geister. Weimar: Duncker.

Kherkhof, K. (1933) Der Krieg gegen die Deutsche Wissenschaft. Halle.

Parsons, T. (1939) “The Professions and Social Structure”. Social Forces 17(4): 457-467. doi: $10.2307 / 2570695$.

Parsons, T. (1951) The Social System. New York: Free Press.

Pettit, G. \& M. Leudet. (1916) Les allemands et la science. Paris: F. Alcan.

Robin, J. (1928) L'oeuvre scientifique: sa protection-juridique. Paris.

Rust, B. (1936) Das nationalsozialistische Deutschland und die Wissenschaft. Hamburg: Hanseatische Verlagsanstalt.

s.n. (1938). “A World Association for Science and Society”. Nature 141(3560): 150-150. doi:10.1038/141150c0.

s.n. (1949) "Against the Bourgeois Ideology of Cosmopolitanism" (Voprosy filosofii 2, November 1948). Current Digest of the Soviet Press 1(1): 3-11.

Sarton, G. (1931) The History of Science and the New Humanism. New York: H. Holt and company.

Scheler, M. (1933) Schriften aus dem Nachlaß: I. Zur Ethik und Erkenntnislehre. Berlin: Der Neue Geist.

Shryock, R. H. (1938) "Freedom and Interference in Medicine". Annals of the American Academy of Political and Social Science 200 (November 1938): 32-59.

Sigerist, H. E. (1938) "Science and Democracy”. Science and Society 2(3): 291-299.

Speier, H. (1938) “The Social Determination of Ideas”. Social Research 5(2): 182-205.

Stark, J. (1936) "Philipp Lenard als deutscher Naturforscher". Nationalsozialistische Monatshefte 7(71): 106-112.

Stern, B. J. (1938) "Restraints upon the Utilization of Inventions". Annals of the American Academy of Political and Social Science 200 (November 1938): 13-31.

Sumner, W. G. (1906) Folkways. Boston: Ginn.

The Council of the American Association for the Advancement of Science. (1938) "Declaration of Intellectual Freedom". Science 87(2245): 10.

Wilson, L. (1941) The Academic Man. New York: Oxford University Press.

Бекон, Ф. (2009) Истинита упутства за тумачење природе - Нови органон \& Велика обнова. Београд: Службени гласник. 
де Токвил, А. (1990) О демократији у Америци. Сремски Карловци: Издавачка књижарница Зорана Стојановића; Титоград: ЦИД.

Robert K. Merton

\section{THE NORMATIVE STRUCTURE OF SCIENCE}

Abstract: In this paper Robert Merton delineates four overarching norms of a scientific ethos: Universalism, Communality, Disinterestedness, and Organized Skepticism. He believes these norms, though nowhere codified, represent commonly held values among scientists. Merton defines and explores each of these norms.

Key words: Science, Scientific ethos, Universalism, Communality, Disinterestedness, Organized skepticism 
